\title{
BRAND EQUITY STIE SYARI'AH DARUL ULUM PURWAKARTA
}

\author{
STIES Syariah Darul Ulum Purwakarta \\ Rina Nurhayati \\ inamaza212@gmail.com
}

\begin{abstract}
Kehadiran Sekolah Tinggi Ilmu Ekonomi Syari'ah Darul Ulum Purwakarta sebagai salah satu Perguruan Tinggi Islam Swasta di Kabupaten Purwakarta yang wilayahnya kini tengah berkembang pesat, memberi angin segar baik bagi para pencari ilmunya yakni para pegawai/karyawan/freshgraduate MA/SMA/SMK, juga bagi STIE Syari'ah Darul Ulum Purwakarta sendiri. Penelitian ini menggunakan Metode Penelitian Kualitatif melalui pendekatan Studi Kasus pada STIE Syari'ah Darul Ulum Purwakarta di Kabupaten Purwakarta, Provinsi Jawa Barat. Brand Equity Sekolah Tinggi Ilmu Ekonomi Syari'ah Darul Ulum Purwakarta terletak pada 4 langkah dalam membangun merek sesuai dengan prinsip Keller ; 1) Identitas Merek (Who Are You), mahasiswa sebagai konsumen mengetahui brand STIE Syari'ah Darul Ulum Purwakarta melalui sosialisasi di sekolah sekolah, kantor - kantor, supermarket, rumah sakit, wilayah industri, selain itu melalui informasi WOM atau Word Of Mouth (dari mulut ke mulut) rekan kerja, pihak yayasan, para dosen, mahasiswa, tim manajemen dan berbagai media, baik media sosial seperti facebook, instagram, dan BBM, banyaknya media luar ruang seperti spanduk plus mini banner yang dipasang di perempatan jalan strategis maupun tempat umum, media cetak melalui penyebaran brosur yang dilengkapi dengan detail biaya kuliah keseluruhan, media massa yakni melalui spot iklan di radio yang tergabung dalam PRSSNI Jabar, maupun dari merchandise yang dipasang logo dan brand STIE Syari'ah Darul Ulum Purwakarta, 2) Makna Merek(What Are You?), brandSTIE Syari'ah DarulUlum Purwakarta merupakan pilihan di tengah persaingan maraknyaPerguruan Tinggi yang muncul di Purwakarta. Seiring dengan adanya SK Dirjen Pendis No 3389 Tahun 2013 yang mengharuskan Sekolah Tinggi Agama Islam memilih rumpun keilmuan yang lebih khusus disesuaikan dengan kondisi wilayah masing-masing. 3) Respon Merek? (What About You?), konsumen menyambut baik brand STIE Syari'ah Darul Ulum Purwakarta, terlebih setelah mendapatkan status Akreditasi B (Sangat Baik) dari Ban PT pada Program Studi Ekonomi Syari'ah, 4) Relasi Merek? (WhatAbout You and Me?), STIE Syari'ah Darul Ulum Purwakartasudah menjalin dengan banyak pihak yangbergerak dalam berbagai bidang baik dalam dan luar negeri.
\end{abstract}

Keyword: Brand Equity, Darul Ulum, Ekonomi Syari'ah

\section{A. PENDAHULUAN}

Perjalanan kehidupan manusia dalam menapaki waktu dan zaman tidak terasa kian berat. Dibutuhkan modal dasar guna mempertahankan hidup yakni melalui capaian ilmu. Gelar akademik seakan menjadi tujuan guna mendapatkan kehidupan yang lebih baik di masa yang akan datang. Tidak dipungkiri, lapangan kerja yang terbatas, hanya dapat dinikmati oleh segelintir bagian saja. Sumber daya manusia di sekitar lokasi industri belum dijamin akan bisa terserap oleh penyedia lapangan pekerjaan, karena masyarakat sekitar wilayah industri harus mampu bersaing dengan para pendatang yang ikut serta berlomba meraih kuota lowongan pekerjaan.

Pemilihan Kabupaten Purwakarta sebagai lokus penelitian ini adalah karena, perkembangan pembangunan yang pesat di Kabupaten Purwakarta. Purwakarta yang terletak diantara dua kota besar Jakarta dan Bandung, yang tengah berbenah diri, sehingga secara kasat mata dapat langsung dilihat bahwa perkembangan pembangunan Kabupaten Purwakarta beranjak semakin indah. Tata kota yang resik menjadi daya tarik pendatang untuk berinvestasi di kota kecil ini, sehingga gelombang masuknya para tenaga kerja dari luar kota Purwakarta, semakin lama semakin meningkat. Hal ini dapat dilihat pada gambar berikut ; 


\section{Gambar 1}

\section{Jumlah Pencari Kerja Menurut Tingkat Pendidikan di Kabupaten Purwakarta Tahun 2016}

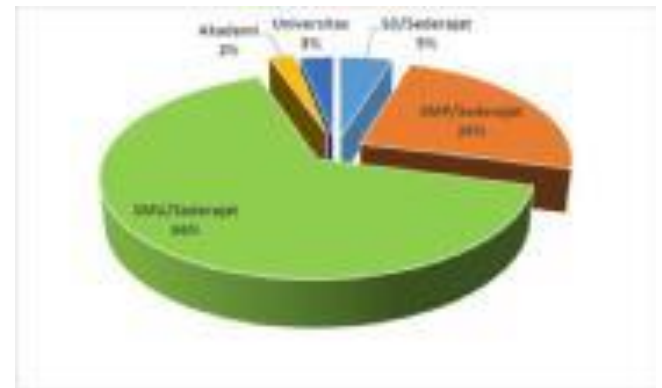

Sumber :Katalog BPS : 1101002.3214 Kabupaten Purwakarta Tahun 2017

Meningkatnya jumlah tenaga kerja yang ada di Purwakarta, menjadi salah satu dasar berdirinya Perguruan Tinggi di Kabupaten Purwakarta. Terdapat 15 Perguruan Tinggi Swasta yang ada di Kabupaten Purwakarta ${ }^{1}$. Untuk ukuran wilayah Kabupaten Purwakarta yang berada di basis industri, tercatat luas wilayah Kabupaten Purwakarta adalah 971,72 Km2 atau sekitar 2,81 persen dari luas wilayah Provinsi Jawa Barat, sehingga keberadaan 15 Perguruan Tinggi Swasta tentu menjadikan persaingan yang sangat ketat dalam berlomba - lomba untuk mendapatkan calon mahasiswa baru.

Pergerakan perekonomian di Kabupaten Purwakarta pada sektor industri, yang berdampak pada pertumbuhan Perguruan Tinggi Swasta dengan rumpun/bidang/jurusan ekonomi. Terdapat beberapa kampus swasta yang memiliki jurusan ekonomi, tetapi tidak semua memiliki peringkat Akreditasi B. Hal ini menjadi salah satu alasan, karena kepemilikan status akreditasi B yang berarti Sangat Baik menjadi sebuah solusi dalam memperluas jalur promosi sebuah perguruan tinggi. Dan hal ini mempermudah lulusan dalam mencari pekerjaan.

Program studi/jurusan Ekonomi dari setiap perguruan tinggi setiap tahunnya cukup tinggi. Di provinsi Jawa Barat terdapat 26 kabupaten/kota ${ }^{2}$, apabila di setiap kabupaten atau kota terdapat 3 kampus dengan jurusan ekonomi dan masing masing jurusan meluluskan 50 orang per tahun, dapat dibayangkan jumlah sarjana ekonomi yang siap bersaing berebut kue lapangan pekerjaan. Berdasarkan hal tersebut, fenomena yang akan diangkat pada penelitian ini adalah kekuatan merek pada perguruan tinggi yang memiliki jurusan atau program studi ekonomi syariah. Mengingat lulusan ekonomi syariah memiliki peluang besar pula dalam merebut kue lapangan pekerjaan. Dan di kabupaten Purwakarta terdapat 3 (tiga) Perguruan Tinggi Agama Islam yang memiliki program studi sama yakni Ekonomi Syari’ah (ES).

Surat kabar harian Vatikan, L’Osservatore Romano, melaporkan bahwa sistem perbankan Islam dapat membantu untuk mengatasi krisis global, seperti yang dilaporkan media Turki. Vatikan mengatakan bank seharusnya mencontoh aturan etika pada keuangan Islam untuk memulihkan keyakinan di antara nasabah mereka pada waktu krisis ekonomi global. ${ }^{2}$ Hal ini menjadi salah satu yang dianggap kekuatan dalam pemilihan brand Sekolah Tinggi Ilmu Ekonomi Syari'ah Darul Ulum dalam memperkuat promosi melalui berbagai media.

Hal lain yang menjadi alas an untuk mengangkat penelitian ini karena peringkat salah satu program studi di STIE Syari'ah Darul Ulum Purwakarta yakni program studi Ekonomi Syari'ah yang Terakreditasi B terpampang pada giantbanner di halaman kampusnya. Ini menjadi daya tarik tersendiri bagi para pengguna jalan yang melintas. Untuk kabupaten dengan wilayah yang tidak seluas kotamadya, mencari kampus dengan peringkat Akreditasi B tidak sesulit di kota besar. Dengan melakukan turun lapangan, berkeliling di wilayah kabupaten Purwakarta serta mengecek keberadaan kampus di Purwakarta yang memiliki Akreditasi B, serta melihat sendiri tampilan promosi giantbanner, maka di dapat 2 (dua) kampus yang 
mencantumkan peringkat Akreditasi B, yakni : STIESyari'ah Darul Ulum Purwakarta dan Akademi Kebidanan Bhakti Asih, keduanya berlokasi di Kabupaten Purwakarta.

Mahasiswa sebagai konsumen pada sebuah perguruan tinggi sehingga keberadaan mahasiswa adalah hal mutlak. Dan mahasiswa memiliki hak untuk mendapatkan peringkat kampusnya dengan status minimal Baik. Jumlah mahasiswa setelah terjadi perubahan brand dari STAI ke STIES mengalami peningkatan setiap tahunnya, sehingga menggugah peneliti untuk mengetahui bagaimana brandequity STIE Syari'ah Darul Ulum Purwakartadi Kabupaten Purwakarta.

Pertanyaan Penelitian, Bagaimana peralihan brand STAI Darul Ulum Purwakarta ke STIE Syari'ah Darul Ulum Purwakarta? dan Bagaimana brand equity STIE Syariah Darul Ulum Purwakarta ?. Tujuan penelitian, Untuk mengetahui peralihan brand STAI Darul Ulum Purwakarta ke STIE Syari'ah Darul Ulum Purwakarta, dan Untuk menggali brand equity STIE Syari'ah Darul Ulum Purwakarta.

Landasan teoritis pada penelitian ini adalah, menurut Undang-undang Merek No. 15 Tahun 2001 pasal 1 ayat 1, Merek adalahTanda yang berupa gambar, nama, kata, huruf - huruf, angka - angka, susunan warna atau kombinasi dari unsur - unsur tersebut yang memiliki daya pembeda dan digunakan dalam kegiatan perdagangan barang atau jasa. Hal ini seperti yang di tunjukkan oleh Kevin L.Keller bahwa A Brand is a name,term, sign, symbol, or combination of them that is designed to identify the goods or services of one seller or group of sellers and to differentiate them from those of competitors (Keller, 2002:151)

Maka brand merupakan kumpulan tanda yang berupa gambar, nama, kata, huruf - huruf, angka - angka, susunan warna atau kombinasi dari unsur - unsur tersebut yang disusun dengan baik, unik dan cantik, agar siapapun yang melihatnya dapat dengan mudah mengingatnya. Sehingga dapat menjadi pembeda dengan pesaing lain, dan menjadi ciri khas tersendiri, serta memiliki falsafah dan makna. Terdapat keinginan serta harapan yang diwujudkan dalam brand itu sendiri, agar lembaga yang didirikan dapat memberi manfaat bagi masyarakat luas dan berdiri untuk kurun waktu jangka panjang.

Langkah - Langkah membangun brand equity ala Kevin L.Keller ; 1) Menyusun identitas merek yang tepat. Perencanaan dan penyusunan identitas merek yang dilakukan oleh pihak Yayasan pada perubahan brand STIE Syariah Darul Ulum dikemas dengan kolaborasi warna, gambar, tanda dan susunan huruf yang memiliki makna yang berarti. 2) Menciptakan merek yang sesuai. Makna pada perubahan brand memberi arti sesuai dengan harapan pengelola yayasan, tim manajemen serta melihat akan kebutuhan pasar. Rumpun ekonomi syari'ah menjadi sebuah pilihan. Darul Ulum memiliki nilai filosofis yang baik. 3) Menstimulasi respon merek yang diharapkan. Sambutan konsumen pada perubahan brand akan dilihat pada jumlah dan kualitas mahasiswa yang mendaftar di STIE Syari'ah Darul Ulum Purwakarta. 4) Menjalin relasi merek yang tepat dengan pelanggan (Tjiptono, 2011:99). Networking yang dibangun membawa dampak yang baik dalam keberlangsungan roda organisasi STIE Syari'ah Darul Ulum Purwakarta.

7 (tujuh) manfaat pokok merek bagi konsumen ; Sebagai identifikasi sumber produk, Penetapan tanggung jawab pada pemanufaktur atau distributor tertentu, Pengurang resiko, Penekan biaya pencarian ( search costs) internal dan eksternal, Janji atau ikatan khusus dengan produsen, Alatsimbolis yang memproyeksikan citra diri, Signal kualitas (Keller dalam Tjiptono, 2011:44). Beberapa peran merek/brand bagi produsen ; Merek mengidentifikasi sumber atau pembuat produk, Merek menyederhanakan penanganan atau penelusuran produk, Merek membantu mengatur catatan persediaan dan catatan akuntansi, Merek juga menawarkan perlindungan hukum kepada perusahaan untuk fitur - fitur atau aspek unik produk, Merek menandakan tingkat kualitas tertentu sehingga pembeli yang puas dapat dengan mudah memilih produk kembali (Kotler\&Keller, 2008:259).

Penelitian ini menggunakan Metode Penelitian Kualitatif melalui pendekatan Studi Kasus pada STIE Syari'ah Darul Ulum Purwakarta di Provinsi Jawa Barat. Hal ini dikarenakan untuk 
wilayah Kabupaten yang tidak luas seperti kotamadya, keberadaan STAI Darul Ulum yang berubah menjadi STIE Syari'ah Darul Ulum Purwakarta menjadi sebuah hal yang menarik untuk diteliti. Metode penelitian kualitatif, karena sesuai dengan salah satu fungsi dan pemanfaatan penelitiannya yaitu digunakan untuk lebih dapat memahami setiap fenomena yang sampai sekarang belum banyak diketahui (Moleong, 2010:7).

Pada penelitian ini pendekatan yang digunakan adalah Studi Kasus, menurut pakar Ilmu Komunikasi, Prof. Deddy Mulyana, mengatakan bahwa : "Studi kasus adalah uraian dan penjelasan komprehensif mengenai berbagai aspek seorang invidu, suatu kelompok, suatu organisasi (komunitas), suatu program, atau suatu situasi sosial. Dengan mempelajari semaksimal mungkin seorang individu, suatu kelompok, atau suatu kejadian, peneliti bertujuan memberikan pandangan yang lengkap dan mendalam mengenai subjek yang diteliti" (Mulyana,2008:201). Sasaran Penelitian pada penelitian ini adalah brand equity dari STIE Syari'ah Darul Ulum Purwakarta itu sendiri, dan pada penelitian ini, penggalian informasi dari para informan dengan teknik purposive, yakni Ketua Yayasan, Mantan Ketua STAI Darul Ulum, Ketua STIE Syari'ah Darul Ulum Purwakarta, Dosen Tetap (alumni), Dosen Tidak Tetap (dosen luar), Alumni dan Mahasiswa. Informan sebagai basis data yang menurut Prof. DR. Lexy J. Moleong, M.A informan adalah "orang yang dimanfaatkan untuk memberikan informasi tentang situasi dan kondisi latar penelitian. Di samping itu pemanfaatan informan bagi peneliti ialah agar dalam waktu yang relatif singkat banyak informasi yang terjaring" (Moleong, 2010:132). Lokasi penelitian ini dilakukan di wilayah Kampus STIE Syari'ah Darul Ulum Purwakarta Purwakarta, Jalan Veteran No 150 Kelurahan Ciseureuh Kecamatan Purwakarta Kabupaten Purwakarta. Sebagai uji keabsahan data, maka digunakan teknik triangulasi data. Triangulasi adalah teknik pemeriksaan keabsahan data yang memanfaatkan sesuatu yang lain. Di luar data itu untuk keperluan pengecekan atau sebagai pembanding terhadap data itu. Teknik triangulasi yang paling banyak digunakan ialah pemeriksaan melalui sumber lainnya (Moleong, 2002:330).

Sebagai data pembanding, maka yang digunakan adalah informasi dari sumber lain yakni Ketua Dewan Pendidikan Kabupaten Purwakarta, Pendiri STIE Syari'ah Darul Ulum Purwakarta dan Kepala Sekolah SMK Bina Budi Kab. Purwakarta. Teknik pengumpulan data pada penelitian ini adalah dengan menggunakan :Pedoman wawancara, informasi didapat dari para informan primer melalui pedoman wawancara yang diberikan kepada informan, lalu para informan menjawab pertanyaan - pertanyaan terbuka. Hal ini juga dilakukan dalam uji keabsahan data dengan formula pertanyaan yang berbeda. Observasi, peneliti melihat langsung ke lapangan berkaitan dengan pengambilan data yang dilakukan sendiri oleh peneliti. Dokumen, data - data yang didapat dari dokumentasi lembaga STIE Syari'ah Darul Ulum Purwakarta. Pengambilan foto dilakukan sendiri oleh peneliti. Studi Kepustakaan, sumber referensi didapat dari buku - buku bacaan, jurnal ilmiah, artikel. Media sosial, pengambilan data dari media sosial facebook dan sebagai media pembanding melalui instagram.

Pengumpulan data yang didapat dari lapangan yang apabila terdapat data yang berupa angka, maka akan paparkan agar supaya terdapat gambaran. Hal ini dikarenakan pada penelitian kualitatif, data kuantitatif dapat digunakan. Prof. Lexy J. Moleong dalam bukunya mengatakan bahwa data yang diperoleh, dibaca, diedit dan dianalisis kemudian diperoleh suatu kesimpulan yang signifikan (Moleong, 2001:103). Pada penelitian ini digunakan teknik analisis data melalui 3 komponen, yakni : Reduksi Data. Proses pemilihan subjek penelitian yang menjadi perhatian penelitian, lalu memfokuskan pada apa yang akan diteliti. Bagian mana yang lebih menarik untuk dikaji. Berdasarkan observasi pra riset, peneliti mencari kampus kampus milik swasta dengan rumpun/bidang/jurusan ekonomi di wilayah Kabupaten Purwakarta yang memiliki predikat Akreditasi B, maka di dapat kampus STIE Syari'ah Darul Ulum Purwakarta. Penyajian Data. Informasi yang didapat dari lapangan, dianalisis dan diolah, baik hasil wawancara, referensi studi kepustakaan, dokumentasi dengan pengambilan foto gedung, data yang didapat dari media sosial facebook maupun instagram. Menarik Kesimpulan. Berdasarkan hasil data dan informasi yang sudahdi analisis lalu dilakukan penarikan kesimpulan, sebagai gambaran mengenai brand equity pada STIE Syari'ah Darul Ulum Purwakarta. Pelaporan. Pelaporan pada penulisan ini adalah dengan menggunakan Pedoman Penulisan Jurnal Ilmiah STIE Syari’ah Darul Ulum Purwakarta. 


\section{B. PEMBAHASAN}

Setiap Produk atau Jasa yang memiliki nama/brand, biasanya memiliki arti tersendiri dengan makna yang baik sesuai dengan cita - cita dan harapan para pengelolanya. Pada Perguruan Tinggi STIE Syari'ah Darul Ulum Purwakarta, Brand atau nama tersebut tidak dibuat sembarangan, tetapi merupakan hasil kesepakatan diantara Ketua Yayasan dan manajemen pengelola kampus. Berikut adalah pembahasan yang didapat dari lapangan riset berdasarkan temuan - temuan hasil deepinterview, dari para informan dan Brand Equity pada Sekolah Tinggi Ilmu EkonomiSyari'ah Darul Ulum Purwakarta terletak pada 4 langkah dalam membangun merek :

\section{Identitas Merek (Who Are You)}

Pada awalnya Ekonomi Syari'ah adalah salah satu program studi yang ada di STAI (Sekolah Tinggi Agama Islam) Darul Ulum Purwakarta sebelum terjadi perubahan nama/brand. Berdampingan dengan program studi Manajemen Pendidikan Islam (MPI). Program studi ekonomi syari'ah di awal pendiriannya merupakan prodi Ekonomi Syari'ah pertama diPurwakarta pada tahun 2010. Yang kemudian dilakukan perubahan brand dari STAI Darul Ulum Purwakarta menjadi STIE (Sekolah Tinggi Ilmu Ekonomi) Syari'ah yang tertuang pada SK Dirjen Pendis No 2906 tahun 2014, perubahan nama/brand ini didasarkan atas instruksi SKDirjen Pendis No 3389 Tahun 2013, sehingga rumpun Ilmu Ekonomi Syari'ah menjadi fokus basis pendidikan di STIE Syari'ah Darul Ulum Purwakarta.

Perubahan ini dilakukan mengingat Kabupaten Purwakarta merupakan salah satu kota industri, serta banyaknya perguruan tinggi swasta yang memiliki jurusan Ekonomi, sehingga sesuai harapan Ketua Yayasan Piksi Ganesha Dr.H. K. Prihartono AH, S.Sos., S.Kom.,MM, karenaSTIE Syari'ah Darul Ulum Purwakarta berada di bawah Kopertais wilayah II Jabar-Banten, maka rumpun Ekonomi Syari'ah dipilih karena memiliki peluang yang besar untuk tumbuh di wilayah industri dan karena sektor perbankan Syari'ah tengah membutuhkan lulusan Ekonomi Syari'ah.

Mahasiswa sebagai konsumen mengetahui brand STIE Syari'ah Darul Ulum Purwakarta melalui sosialisasi di sekolah sekolah, kantor - kantor, supermarket, rumah sakit, wilayah industri, selain itu melalui informasi WOM atau Word Of Mouth (dari mulut ke mulut) rekan kerja, pihak yayasan, para dosen, mahasiswa, tim manajemen dan berbagai media, baik media sosial seperti facebook, instagram, dan BBM, banyaknya media luar ruang seperti spanduk plus mini banneryang dipasang di perempatan jalan strategis maupun tempat umum, media cetak melalui penyebaran brosur yang dilengkapi dengan detail biaya kuliah keseluruhan, media massa yakni melalui spot iklan di radio yang tergabung dalam PRSSNI Jabar, maupun dari merchandise yang dipasang logo dan brand STIE Syari'ah Darul Ulum Purwakarta.

Lokasi kampus di tengah kota dan dilalui oleh semua jenis trayek kendaraan umum menjadi salah satu daya tarik tersendiri. Di mana kampus STIE Syari'ah Darul Ulum Purwakarta sebagai salah satu kampus berbasis Islam di bawah Kementerian Agama Republik Indonesia, mampu bersaing dalam meraih pasar. Dan letak yang strategis menjadi sebuah kemudahan bagi para mahasiswa dalam proses pembelajaran, serta mempermudah dalam proses promosi kepada masyarakat atau pengguna jalan raya, karena masyarakat dapat melihat langsung plang namaSTIE Syari'ah Darul Ulum Purwakarta Purwakarta yang dilengkapi dengan jenjang S1 (Sarjana) dan program studinya. Berikut adalah tampilan gedung Kampus STIE Syari'ah Darul Ulum Purwakarta :

\section{Gambar 2}

\section{Kampus STIE Syari'ah Darul Ulum Purwakarta}

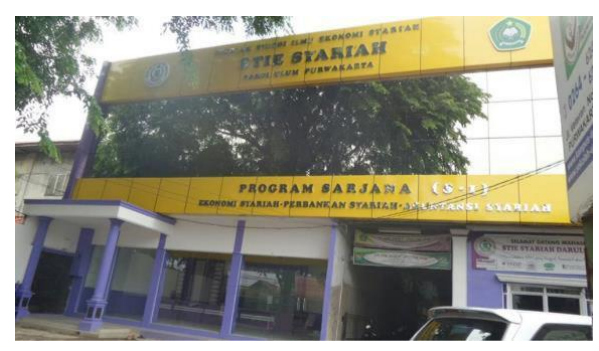


Sumber : dokumentasi peneliti, 2017

Selain dari lokasi gedung perkuliahan dengan plang nama yang terlihat oleh berbagai kendaraan atau pengguna jalan, salah satu media promosi yang aktif digunakan guna menembus waktu dan batas wilayah adalah promosi melalui media sosial, sehingga calon konsumen dapat langsung mengakses melalui web site ;www.kampus-indonesia.com. Para calon mahasiswa dapat dengan mudah mencari pada aplikasi Facebook dengan mengetikkan STIES Darul Ulum Purwakarta pada kolom search, maka akan muncul tampilan profile akun tersebut, yang salah satunya apabila di scrolldown akan tampak banyak informasi seperti di bawah ini :

\section{Gambar 3Akun Facebook STIES Darul Ulum Purwakarta}

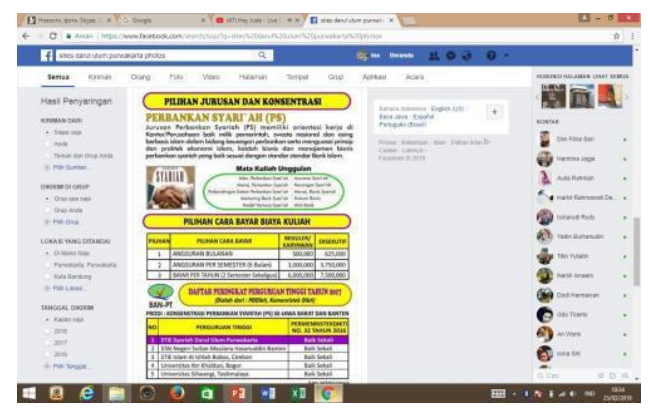

Sumber :facebookSTIES Darul Ulum Purwakarta, 2017

Pada tampilan lama tersebut, para pencari kampus dapat dengan mudah mengkalkulasikan, antara kemampuan menuntut ilmu dengan kemampuan financial. Hal ini dilakukan untuk mempermudah masyarakat dalam proses pengambilan keputusan memilih tempat kuliah.

\section{Makna Merek (What Are You ?)}

Brand STIE Syari'ah Darul Ulum Purwakartamerupakan pilihan di tengah persaingan maraknyaPerguruan Tinggi yang muncul di Purwakarta. Seiring dengan adanya SK Dirjen Pendis No 3389 Tahun 2013 yang mengharuskan Sekolah Tinggi Agama Islam memilih rumpun keilmuan yang lebih khusus disesuaikan dengan kondisi wilayah masing-masing. Brand equitytidak hanya terkait nama, tetapi logo menjadi salah satu ciri dari sebuah merek. Berikut adalah logo STIESyari'ah Darul Ulum Purwakarta :

\section{Gambar 4}

Logo STIE Syari'ah Darul Ulum Purwakarta

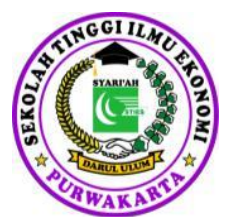

Sumber : STIES Darul Ulum, 2017

Pembahasan terkait logo STIE Syari'ah Darul Ulum Purwakarta yang memiliki makna ; lingkaran berwarna ungu adalah karena ungu dikenal memiliki nilai positif yang tinggi dalam tataran aura warna yang diharapkan kampus STIES dapat memberikan energi yang baik dan bisa berperan aktif dalam membentuk lulusan atau sumber daya insani yang unggul dan mampu berkompetisi di era persaingan global.

Gambar toga adalah symbol dari jenjang perguruan tinggi yaitu Strata 1 (S1) dengan lulusannya adalah Sarjana Ekonomi. Kapas dan padi sebagai symbol lulusan STIES Darul Ulum memiliki nilai guna yang tinggi di tengah masyarakat, dan keberadaan lulusannya 
senantiasa dibutuhkan dalam percaturan perekonomian, karena salah satu peran mahasiswa adalah sebagai agent ofchange.

Simbol jabat tangan pada ujung bawah kapas dan padi adalah di dalam almamater kampus STIE Syari'ah Darul Ulum Purwakarta, hendaknya dijauhkan dari rasa senioritas dan junioritas karena almamater lebih mengedepankan sistem kekeluargaan. Dengan sistem ini maka diharapkan suasana yang harmonis dan kondusif dapat terwujud, sehingga proses kegiatan Tridharma Perguruan Tinggi (Pendidikan dan Pengajaran, Penelitian serta Pengabdian Kepada Masyarakat) dapat terlaksana dengan baik.

Gambar kotak hijau berbulan pada bagian tengah logo adalah sebagai simbol warna yang teduh, segar dan bulan sebagai pemancar cahaya di kegelapan. Diharapkan kelak, lulusan STIE Syari'ah Darul Ulum Purwakarta akan mampu memberikan banyak solusi dalam kehidupan berbangsa dan bernegara dan mampu mengentaskan permasalahan sosial. Sedangkan arti dari Darul Ulum sendiri senada dengan salah satu pendiri STIE Syari'ah Darul Ulum Purwakarta, dr. H. Ueng Suhaeli adalah, darul yang berarti gudang, dan ulum yang memiliki arti jamak dari ilmu, yakni ilmu - ilmu. Yang diharapkan ke depan bahwa lulusannya akan menjadi gudang ilmu di tengah masyarakat, mampu bersama - sama mengentaskan permasalahan sosial, sehingga selain dengan banyknya mata kuliah yang kompeten juga sesuai dengan tuntutan jaman, bahwa STIE Syari'ah Darul Ulum Purwakarta akan memiliki banyak program studi sehingga dapat memenuhi kebutuhan pasar. Kini di STIE Syari'ah Darul Ulum Purwakarta sendiri terdapat 3 (tiga) program studi yakni ; Ekonomi Syari'ah, Perbankan Syari'ah dan Akuntansi Syari'ah (onprocess).

Setiap Perguruan Tinggi berlomba dalam memenuhi kebutuhan pasar. Terutama peringkat akreditasi menjadi modal utama dalam eksistensinya di tengah masyarakat. Pada tahun 2016, berdasarkan hasil audit eksternal yang dilakukan oleh BAN PT pada 2016, STIE Syari'ah Darul Ulum Purwakarta mendapatkan peringkat Akreditasi B (sangat baik). Dengan terbitnya SK Ban PT No. 1542/SK/BAN-PT/Akred/VIII/2016, hal ini menjadi spirit terbesar dalam mengembangkan posisinya di tengah banyaknya perguruan tinggi di wilayah Kabupaten Purwakarta. Sehingga harapan besar bagi almamater civitas akademika STIE Syari'ah Darul Ulum Purwakarta adalah mendapatkan banyak anggota keluarga (mahasiswa) baru yang akan bersama - sama menuntut ilmu dalam rumpun ilmu ekonomi syari'ah.

\section{Respon Merek ? (What About You?).}

Konsumen menyambut baik brand STIE Syari'ah Darul Ulum Purwakarta, terlebih setelah mendapatkan status Akreditasi B (Sangat Baik) dari Ban PT pada Program Studi Ekonomi Syari'ah, hal ini dibuktikan dengan adanya SK Ban PT No. 1542/SK/BANPT/Akred/VIII/2016 yang menyatakan bahwa Program Studi Sarjana Ekonomi Syari'ah, Sekolah Tinggi Ilmu Ekonomi Syari'ah Darul Ulum Purwakarta terkareditasi dengan peringkat Akreditasi B. dan hal ini sebagai salah satu modal agar kepercayaan bagi para calon mahasiswa, mahasiswa sebagai konsumen, alumni, para dosen, mitra, relasi dan users.

Peringkat Akreditasi B pada program studi Ekonomi Syari'ah sebagai salah satu modal utama dari STIE Syari'ah Datul Ulum Purwakarta, yang menempati peringkat 1 (pertama) sebagai satu - satunya program studi Ekonomi Syari'ah yang terakreditasi B se Jawa Barat dan Banten, dalam ranah Perguruan Tinggi Agama Islam Swasta (Gambar 3), hal ini tertuang dalam Permenristekdikti No.32 Tahun 2016. Dan di publikasikan dalam semua kegiatan internal dan eksternal, agar kepercayaan publik dapat senantiasa terjaga.

Respon konsumen terhadap brand STIE Syari'ah Darul Ulum Purwakarta dapat di lihat pada peningkatan jumlah mahasiswa yang mendaftar. Pada saat awal perubahan nama STAI menjadiSTIE Syari'ah di tahun 2014, terjadi lonjakan penerimaan mahasiswa baru yang sangat signifikan. Berikut adalah gambaran mahasiswa baru pada saat awal perubahan brand nama kampus STIE Syari'ah Darul Ulum Purwakarta ; 


\section{Grafik 1Peningkatan Jumlah Mahasiswa Tahun 2014}

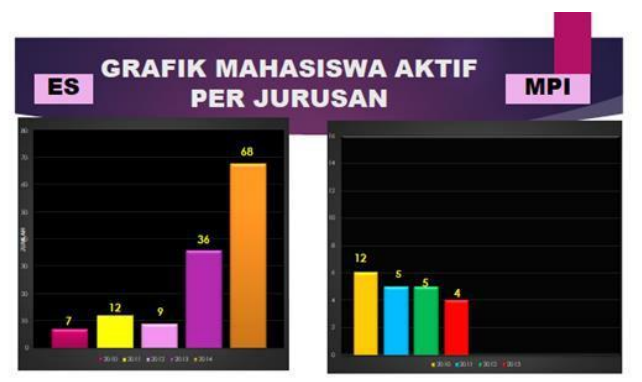

Sumber :STIE Syari'ah Darul Ulum Purwakarta, 2017

Paparan dari grafik tersebut di awal perubahan brand dari STAI Darul Ulum Purwakarta menjadi STIE Syari'ah Darul Ulum Purwakarta, masih terdapat program studi MPI (Manajemen Pendidikan Islam) yang saat tersebut (2014), sudah tidak ada lagi pendaftar. Sehingga sesuai dan fokus dengan brand STIE Syariah Darul Ulum Purwakarta dalam rumpun Ekonomi Syari'ah, maka pada tahun 2015, hadir program studi baru yakni Perbankan Syariah yang kini sudah memiliki mahasiswa angkatan ke III.

Sehingga diharapkan lulusan STIE Syari'ah Darul Ulum dari dua program studi tersebut dapat memenuhi kebutuhan pasar, yang salah satunya adalah dapat melengkapi dan memenuhi Sumber Daya Manusia Insani di bidang perbankan syariah maupun perbankan konvensional, selain bidang - bidang lain atau membuka usaha mandiri.

Melalui sosialisasi yang dilakukan dengan teratur dan terencana, semua yang ada di dalam civitas akademika turut serta dalam penyebaran informasi mengenai STIE Syariah darul Ulum Purwakarta. Tim manajemen yang berada dalam struktur organisasi institusi berperan aktif melakukan promosi mandiri baik secara personal dari mulut ke mulut, maupun melalui media sosial masing - masing.

Seperti yang di sampaikan oleh Mantan Ketua STAI/STIE Syariah Darul Ulum Purwakarta (periode 2012 - 2014), Drs. H. Moch Rafe'i., MM bahwa semua pihak yang ada di dalam institusi STIE Syariah Darul Ulum Purwakarta, diberikan pemahaman sejak awal agar memiliki sense of belonging yang tinggi. Karena almamater kampus dibesarkan oleh orangorang yangada di dalamnya.

Terkait dengan trust atau sikap percaya pada lembaga STIE Syari'ah Darul Ulum Purwakarta, mahasiswa mengaku percaya, karena 4 (empat) angkatan lulusannya banyak yang diterima kerja di instansi lain, menjadi dosen di perguruan tinggi lain dan di rekrut menjadi Dosen Tetap STIE Syari'ah Darul Ulum Purwakarta sendiri, serta mampu membuka lapangan pekerjaan mandiri di lingkungan tinggalnya masing - masing. Lulusan mampu mengamalkan ilmunya, terbukti lulusannya tidak sedikit yang menjadi ustadz ustadzah berbekal ilmu yang didapat, dan memasyarakatkan ilmu ekonomi syari'ah.

\section{Relasi Merek? (What About You and Me?).}

Perjalanan dalam membawa kampus dalam kompetisi global tidaklah semudah membalikkan telapak tangan. Perubahan brand menjadi STIE Syari'ah Darul Ulum Purwakarta kini semakin melebarkan sayapnya dengan menjalin kerjasama baik lokal, regional dan internasional. Untuk lokal sudah menjalin dengan banyak pihak yang bergerak dalam berbagai bidang usaha. Lingkup regional, nasional, dan internasional kemitraan dilakukan melalui keikutsertaan dalam seminar - seminar yang di dalamnya terdapat sesi penandatangan MoU. Kegiatan kemitraan atau kerjasama dapat berupa pelaksanaan kegiatan baik akademis dan non akademis. Berikut adalah jalinan kerjasama dengan beberapa lembaga/instansi yang sudah dilakukan 
Tabel 1. Jalinan Kerjasama MoU

\begin{tabular}{|c|c|}
\hline Tingkat & Jumlah \\
\hline Lokal & 23 \\
\hline Regional & 76 \\
\hline Internasional & 18 \\
\hline
\end{tabular}

Sumber :STIE Syari'ah Darul UlumPurwakarta, 2018

Menjalin kerjasama dalam sebuah institusi perguruan tinggi merupakan kegiatan yang wajib dilaksanakan. Bukan hanya bidang akademik saja, tetapi kegiatan non akademik pun harus terlaksana dengan baik. Menurut Ketua STIE Syari'ah Darul Ulum Purwakarta, Ahmad Damiri, S.Sy.,M.Ag, MoU yang sudah di lakukan oleh pihak STIE Syariah Darul Ulum Purwakarta diharapkan dapat bermanfaat bagi semua pihak terutama bagi lulusan, mengingat STIE Syari'ah Darul Ulum Purwakarta tidak menyalurkan lulusannya untuk bekerja di perusahaan lain, tetapi diharapkan dapat menjadi para entrepreneur muslim yang unggul dan mampu bersaing di kancah perekonomian baik syari'ah maupun konvensional, dengan membuka lapangan pekerjaan. Dapat mengaplikasikan semua ilmu yang sudah didapat selama masa perkuliahan. Dan berperan aktif dalam masyarakat. Serta dapat mengamalkan ilmunya demi kemajuan perekonomian syari'ah. Tetapi dengan adanya penandatanganan MoU, diharapkan hal yang bersifat akademis dan non akademis lainnya dapat terjalin dengan baik. Menurut Ketua Dewan Pendidikan Kabupaten Purwakarta Periode (2014 - 2018 ), Dr.H. Anang Abdul Razak., M.Pd yang dikonfirmasi melalui wawancara mengenai perubahan nama/brand baru yaitu STIE Syari'ah Darul Ulum Purwakarta adalah " Bagus, karena lebih cepat diketahui oleh yang membaca tentang kekhususan ilmu yang didalaminya".

Keinginan para users pada perubahan kurikulum sudah dilaksanakan, hal ini tertuang dalam kurikulum berbasis KKNI yang dilakukan pada lokakarya kurikulum tahun 2016. Selain dari mata kuliah yang berbasis KKNI, juga dilaksanakan Uji Kompetensi yang dilaksanakan 1 tahun sekali setelah Ujian Akhir Semester, dimana setiap lulusan di STIE Syariah Darul Ulum Purwakarta akan mendapatkan SKPI (Surat Keterangan Pendamping Ijasah) dari hasil uji kompetensi tersebut, hal ini sesuai dengan instruksi Undang - undang No. 12 Tahun 2012, serta adanya pelaksanaan praktikum di setiap semester yang akan memacu prestasi dan keahlian para mahasiswa.

\section{KESIMPULAN}

Brand equity merupakan modal bagi sebuah institusi pendidikan agar kepercayaan publik dapatdiraih, dipertahankan bahkan di tingkatkan. Mengingat brand equity adalah sebuah investasi jangka panjang apabila di pelihara dengan baik. Sehingga selain dari aspek kuantitas agar mendapatkan banyak mahasiswa baru, tetapi aspek kualitas pendidikan dan lulusan, harus seiring dengan brand yang kuat, yang sudah melekat di benak konsumen, bahkan di benak pihak eksternal lainnya. Kurikulum yang berbasis KKNI dan lulusan yang unggul, kompeten dan berakhlakul karimah.

Kekuatan brand STIE Syari'ah Darul Ulum Purwakarta selain dari dikenalnya nama STIE Syari'ah Darul Ulum Purwakarta itu sendiri adalah luasnya jalinan kemitraan yang dibangun melalui kerjasama yang tertuang dalam MoU, dan kepercayaan dari para mahasiswa, juga dengan mudahnya diterima di masyarakat dalam berbagai kegiatan Pengabdian Kepada Masyarakat. Kualitas kurikulum berbasis KKNI yang sesuai dengan keinginan pasar, dan adanya pelaksanaan Uji Kompetensi yang dilakukan setiap 1 (satu) tahun sekali, serta 
pelaksanaan praktikum berbasis ibadah dan kompetensi setiap semester, merupakan penunjang dalam kekuatan mereknya.

Kepercayaan dari mahasiswa khususnya, harus di pertahankan dan ditingkatkan, baik kegiatan pelayanan akademis dan non akademis,Sehingga kekuatan merek/brand STIE Syariah Darul Ulum Purwakarta menjadi kunci pokok dalam mengembangkan almamater yang kian berkembang di tengah era pasar bebas.

\section{DAFTAR PUSTAKA}

Keller, Kevin L. Branding and Brand Equity. Cambridge, Massachusetts. Marketing Science Institute

Kotler, Phillip dan Kevin L.Keller. 2008. Manajemen Pemasaran Edisi ke 13, Jilid I. Jakarta. Erlangga dan Power MacPro

Moleong, Lexy J. 2010. Metode Penelitian Kualitatif. Bandung. Remaja Rosdakarya Mulyana, Deddy. Metode Penelitian Kualitatif. Bandung.

Rosda Karya

Tjiptono, Fandy. 2011. Manajemen dan Startegi Merek. Yogyakarta.

Andi Wahyudi, Sandy. Entrepreneurial Branding and Selling.

Yogyakarta. Graha Ilmu

Undang - undang No 15 Tahun 2001

Katalog BPS : 1101002.3214 Kabupaten Purwakarta Tahun 2017

1. (http://akreditasi.net/category/jawa-barat/purwakarta/)

${ }^{2}$ http://www.ekonomiSyari'ah.org/4121/vatikan-menawarkan-prinsip-keuangan-islamkepada-bank-bank-di-barat/ 